\title{
Pharmacognostical Standardization \& Phytochemical Evaluation of Alphonsea sclerocarpa Thwaites Bark \& Leaves
}

\author{
Venkata Naga Anantha Sandhya Rani Nandyala ${ }^{1 *}$ and Kothapalli Bonnoth Chandrasekhar ${ }^{2}$
}

\section{Venkata Naga Anantha Sandhya Rani Nandyala ${ }^{1 *}$ Kothapalli Bonnoth Chandrasekhar ${ }^{2}$}

'Oil Technological and Pharmaceutical Research Institute (OTPRI), Department of Pharmacognosy, Jawaharlal Nehru Technological University Anantapur (JNTUA), Ananthapuramu-515001, Andhra Pradesh, INDIA. ${ }^{2}$ Academic Assistant, (OTPRI) JNTUA, Ananthapuramu-515001 INDIA.

\section{Correspondence}

Venkata Naga Anantha Sandhya Rani Nandyala,

Academic Assistant, (OTPRI) JNTUA, Ananthapuramu-515001 INDIA.

Phone no: 8500023869 / 7995394139

E-mail: sandhyarani.nandyala@gmail.com History

- Submission Date: 02-09-2016:

- Review completed: 5-10-2016;

- Accepted Date: 20-10-2016.

DOI : 10.5530/pj.2017.2.32

Article Available online

http://www.phcogj.com/v9/i2

\section{Copyright}

(C) 2017 Phcog.Net. This is an openaccess article distributed under the terms of the Creative Commons Attribution 4.0 International license.

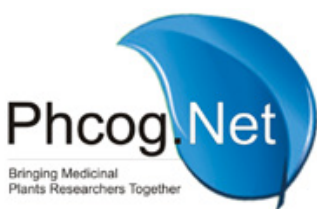

\begin{abstract}
Introduction: The genus Alphonsea sclerocarpa Thwaites (Annonaceae) includes species distributed widely in the tropical areas. Whole plant of Alphonsea sclerocarpa is traditionally believed for its eminent therapeutic benefits. Despite its medicinal properties the plant seems to be less explored and hence this research aims at exploring the Pharmacognostical parameters for standardization. Physicochemical and Phytochemical analysis was also carried out to establish quality control parameters for the drug. Methods: Morphoanatomical (Transverse Section of Leaf Lamina \& Margin, Radial Longitudinal Section \& Tangential Longitudinal Section of phloem in bark) and Powder microscopic analysis were carried out by employing Formalin fixed as well Macerated specimens. Physicochemical Parameters like Loss on drying, Ash Value, Extractive values etc were carried out as per WHO guidelines. Phytochemical Analysis was also carried out and the phytochemical profile was established. Results: Transverse section of Leaf revealed the presence of Plano convex vascular bundles. Ensheathed by a bundle of sclerenchyma. Transverse section of bark has shown the presence of highly compressed, heavily suberised phellem cells. Tangential longitudinal section (TLS) revealed the presence of Spindle shaped bi or Multi seriate medullary rays. In Radial longitudinal section (RLS) the phloem cells appear rectangular and thin walled. Powder microscopy revealed the presence of Fibres, fibre-tracheids and Calcium oxalate crystals. Total ash value of Bark \&Leaf was found to be 8.75 \& 7 \% respectively. Conclusion: The established Pharmacognostical, Physico-chemical \& Phytochemical parameters will suffice for establishing Monographs for the plant drug.
\end{abstract}

Key words: Monograph, Radial Longitudinal Section, Standardization, Tangential Longitudinal Section.

\section{INTRODUCTION}

Nature has provided a boon in the form of Flora \& Fauna to the mankind. ${ }^{1-2}$ Pharmacological and therapeutic potency of these flora \& fauna can be attributed to the diverse inherent chemical compounds present within them. Certain of the commonly available plants show profound medicinal properties viz. Anti-oxidant, Anti-parasitic and Anti-cancer activities among which plants of the Annonaceae family are the least explored. It is distributed pantropically and comprises approximately 123 genera and 2100 species. $^{3}$ Annonaceae is considered to be the large scale diligence for the production of alkaloids (29\% of total alkaloids) especially of Benzylisoquinoline type. Among the members of Annonaceae, Alphonsea sclerocarpa thwaites is least explored into its pharmaceutical benefits and is thus adopted for the present study. Alphonsea sclerocarpa is a under storey tree with Oblong to Lanceolate or elliptic simple, alternate leaves ranging in size from $2.5-6.5 \times 2-3 \mathrm{~cm}$, fissured bark, flowers in cymes and fruits in the form of aggregated berries belonging to the family Annonaceae. The plant is widely distributed in tropical parts of the world especially Srilanka and Southern parts of India. In South India the plant occupies its space in Western Ghats and South sahyadri hills. ${ }^{4}$ It is commonly named as Pulusu Mamidi by the tribes. ${ }^{5}$ Pharmacognosy deals basically with standardization as any of the products from herbal origin viz. Herbal Cosmetic or Herbal syrup made from pharmacologically important constituents can be introduced into the market only upon passing through all the Quality control parameters. ${ }^{6}$ In other words it is that only the standardized product is acceptable for human consumption. Continuous supply of standardized herbal medicines is only ensured when we have a proper control on starting material or Crude form of drug. In ensuring the quality of Herbal raw material as well the product Pharmacognostical, Physico-chemical and Phytochemical evaluations play a pivotal role. Hence, in the present work Pharmacognostical and Phytochemical parameters have been studied for the Bark and Leaf of the Plant.

\section{MATERIALS \& METHODS}

Collection, Authentication and Extraction of Plant material

Fresh Leaves and bark were collected from agasthyamalai hills in the month of June 2016. The Leaf and bark of the plant species were identified and authenticated by Prof. P. Jayaraman at Plant Anatomy Research Centre with PARC/2016/ 3289. The Leaves and Bark were washed under tap water; air dried, homogenized to fine powder and sealed in air tight bottles for future use. Leaf and bark powders were defatted with petroleum ether and were subjected to successive solvent extraction using Soxhlet apparatus. ${ }^{7}$ The solvent 
was removed by using Rota evaporator and the dried crude extracts were stored in air tight containers.

\section{Pharmacognostic characterization Microscopic characteristics}

The obtained Leaf and Bark samples were fixed in a mixture of Formalin, Acetic acid \& ethyl alcohol and after 24 hrs they were dehydrated with Tertiary butyl alcohol. Later on the samples were infiltrated by the gradual addition of Paraffin wax and the blocks thus obtained were sectioned using Rotary Microtome. The specimens were dewaxed and stained using Toluidine Blue, Saffranin etc. Powder of leaf and bark were cleared using Sodiumhydroxide and mounted in Glycerine after staining with reagents. Photomicrographs of the above were taken using a Nikon labphoto2 Microscopic unit. ${ }^{8-9}$

\section{Physicochemical Parameters:}

Evaluation of Physicochemical parameters like Total ash, Water soluble ash, acid insoluble ash, loss on drying, Water, Alcohol, Chloroform and Petroleum ether soluble extractive values were carried out as per the guidelines of WHO. ${ }^{10}$ Presence of Heavy metals like Lead and Mercury was also ruled out.

\section{Fluorescence Analysis}

Powders of leaf and bark were treated with several reagents and exposed to visible, short UV (254 nm) \& Long Ultraviolet (365 nm) light. ${ }^{11}$

\section{Phytochemical Analysis}

Powders of leaf and bark were successively extracted with petroleum ether, Chloroform and Methanol in Soxhlet apparatus. All the extracts were concentrated by removing the solvent using Rotavapor and then evaporated on a water bath till dried. The extract obtained was weighed and the percentage yield was calculated in terms of air dried weight of plant material. The extracts were subjected to preliminary phytochemical analysis as per standard procedures. ${ }^{12}$ As the plant is found to have alkaloids the extracts are quantitatively screened for their alkaloid content using Gravimetric Analysis. ${ }^{13}$

\section{RESULTS}

\section{Pharmacognostic studies}

Microscopic Characteristics

Leaf

Epidermis: Transverse section of leaf has shown vertically oblong, thick walled cells on the adaxial side, small squarish thick walled cells on the abaxial side (Figure 1).

Midrib: It is seen flat on the adaxial side and Plano-convex on the abaxial side. Midrib is enclosing a single large Plano-convex vascular bundle Ensheathed by sclerenchyma. The ground tissue consists of compact parenchyma cells (Figure 2).

Lamina: The leaf is said to be dorsi-ventral as both the adaxial and abaxial sides can be differentiated. The mesophyll tissue includes compact short columnar palisade cells and about 6 layers of spongy parenchyma cells embedding circular vascular bundles (Figure 3).

\section{Bark}

Transverse section of Entire Bark: The surface of the bark was found to be highly rough and deeply fissured. The fissures are deep and wide at the surface and become narrow and canal like towards interior. Periderm consists of thick Phellem and Phelloderm. The phellem cells are compressed, heavily suberised and appear dark (Figure 4). Periderm cells have lignified tangential walls (Figure 5). Inner to Periderm is the secondary phloem which forms the major part of the bark. Secondary phloem is differentiated into outer thicker collapsed phloem and inner thin Non-collapsed phloem. In collapsed phloem the ground parenchyma cells are dilated. The phloem elements are crushed into thick tangential horizontal layers. These dark bands alternate with dilated rays and phloem parenchyma cells (Figure $6 \& 7$ ). Non-collapsed phloem shows the presence of Sieve elements and parenchyma cells. These phloem rays are narrow.

Tangential Longitudinal Section (TLS) of Phloem: In this view the phloem rays appear as spindle shaped bodies. They are vertically elongated and are either bi or multi seriate. The phloem rays are non-storied. Sieve elements, Phloem parenchyma cells and fibres are in vertical rows. The sieve elements have oblique sieve plates (Figure 8 \& 9).

Radial Longitudinal Section (RLS) of Phloem: In this view, the phloem rays appear in the form of flat, horizontal ribbon. The ray cells appear storied. Sieve element, phloem fibres and phloem parenchyma occur in vertical series at right angles to the phloem rays (Figure 10).

\section{Powder Microscopy}

Powder microscopic study of leaf \& bark revealed the presence of Fibres, Fibre-tracheids, epidermal layer, Crystals, Periderm cells, parenchyma cells and phloem rays.

Fibres: These are long, thin and tapering having narrow lumen and lignified walls in leaf powder (Figure 11).

Fibre-tracheids: The cells are long, uniformly thick with tapering ends. The cells have narrow slit like pits in bark powder. (Figure12).

Epidermal layer: Epidermal cells of leaf are small, square shaped and have thick slightly wavy anticlinal walls (Figure 13). Stomata are of paracytic type in the leaf (Figure 14)

Calcium oxalate crystals: Calcium oxalate crystals are of prismatic type and vary from rhomboidal, rectangular type in bark (Figure 15).

Periderm cells: The cells are polygonal in outline, either thin or thick walled. Brachy sclereids are polyhedral with highly thick walled lignified cell wall and wide lumen (Figure 16).

Parenchyma cells: Parenchyma cells of bark are polyhedral thin walled, transparent with dense cytoplasm and some cell inclusions.

Phloem rays: These are multicellular and possess thick walls in bark (Figure 17).

\section{Physico-chemical Analysis}

The results of different physico-chemical analysis were tabulated (Table 1). Phytochemical Analysis: Powdered leaf and bark were subjected to successive solvent extraction using soxhlet and the resultant extracts were subjected to preliminary phytochemical screening as per the standard procedures and the results were tabulated in (Table 2).$^{14}$ Fluorescence analysis results were also tabulated (Table 3).

\section{DISCUSSION}

For the Commercialization of plant based formulations, quality \& identity of starting material is utmost essential which can be best established by Pharmacognostical Standardization. Pharmacognostical characters are helpful in confirming the identity and in the determination of purity, quality of crude drug. As per WHO microscopic characters help in establishing identity and purity ${ }^{15}$ and hence the present Pharmacognostical research is aimed at establishing the Pharmacognostical standards for Alphonsea sclerocarpa.

Leaves have shown paracytic stomata and the bark has shown the presence of Prismatic Calcium Oxalate crystals and Collapsed, Noncollapsed Phloem. These features will be helpful in the future identification of the plant.

Physico-chemical evaluation of powder helps in detecting the adulteration. Loss on drying is performed as the percentage of active chemical constituents is measured on air -dried basis. Total ash values of $8.75 \%$ for bark and $7 \%$ for the leaf indicates that there are no traces of inorganic 


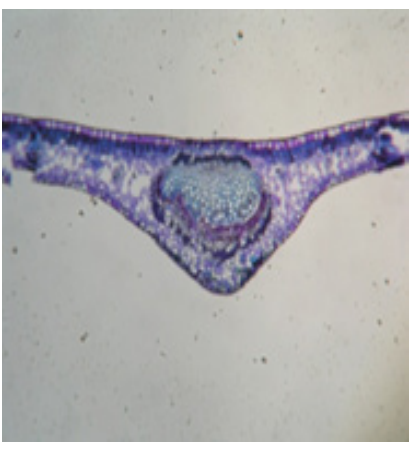

Figure 1: T.S of entire Leaf

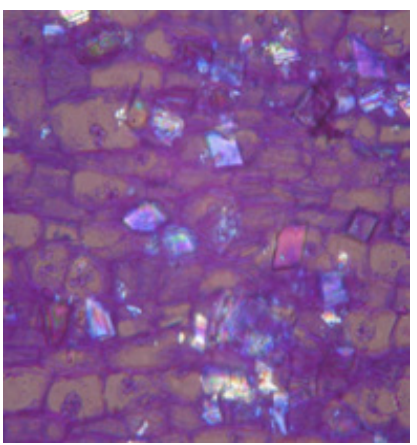

Figure 5: Periderm cells-Bark

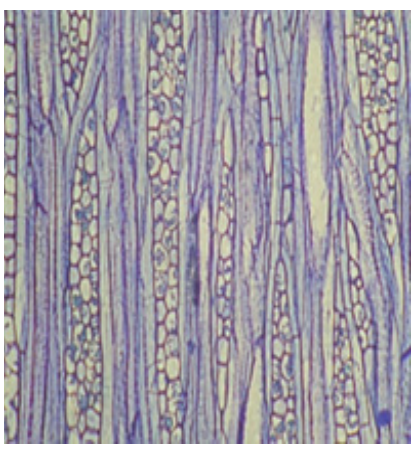

Figure 9: TLS of Phloem with Sieve tubes and Oblique plates

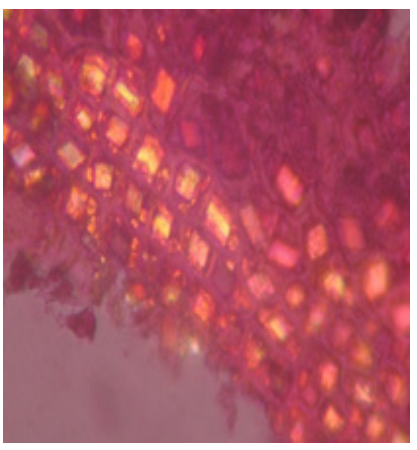

Figure 13: Epidermal Cells- Leaf

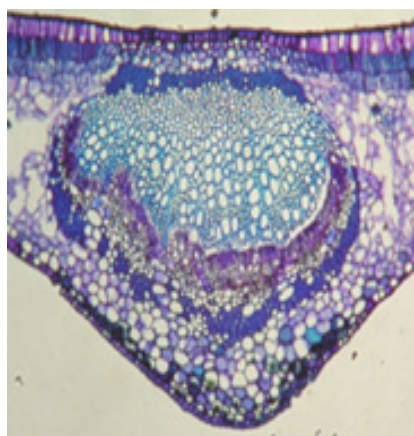

Figure 2: Leaf Midrib

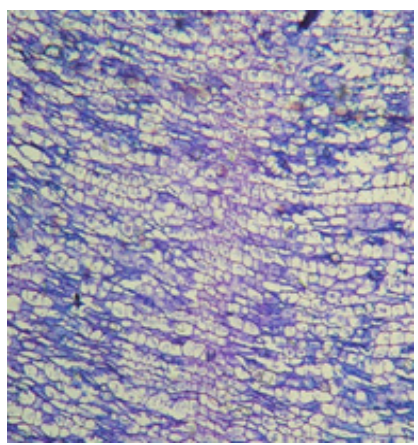

Figure 6: Phloem \&Dilated rays

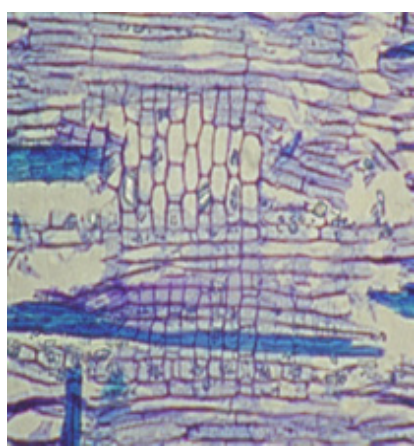

Figure 10: RLS of Phloem

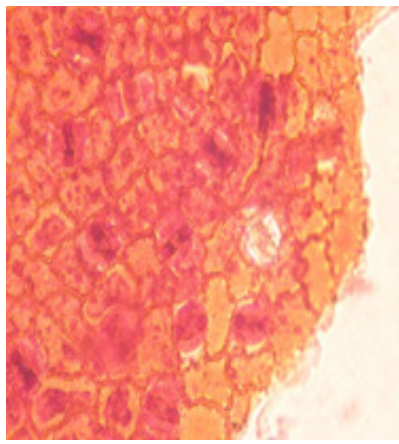

Figure 14: Paracytic stomata

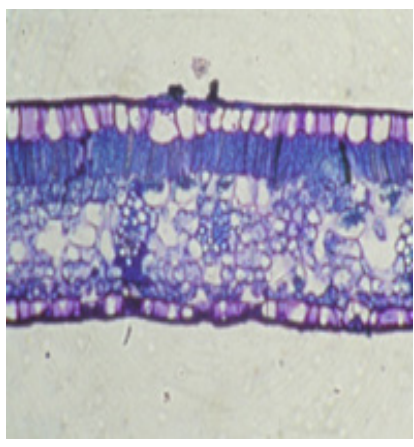

Figure 3: Leaf Lamina

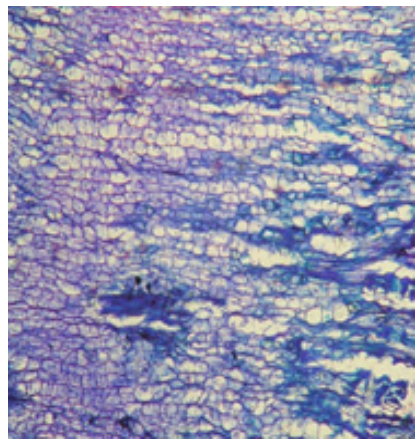

Figure 7: Phloem parenchyma

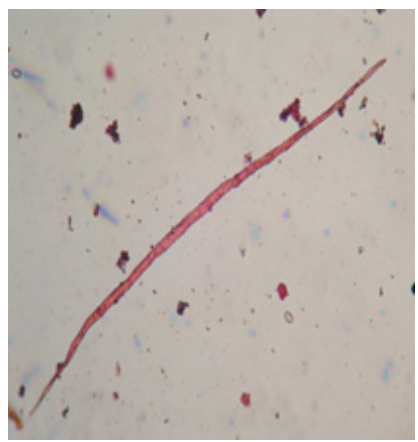

Figure 11: Leaf Powder -Fibres

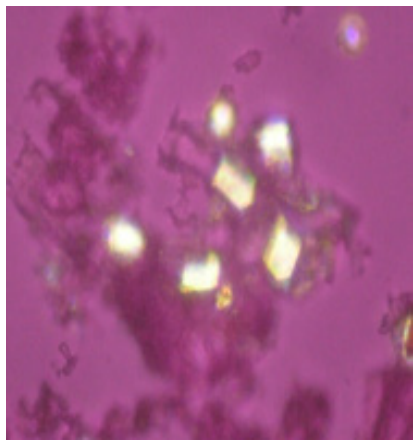

Figure 15: Calcium oxalate crystals

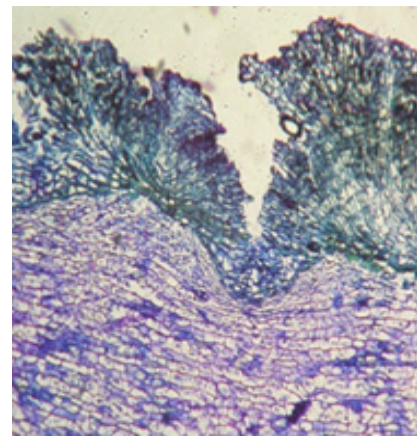

Figure 4: Bark showing phellem

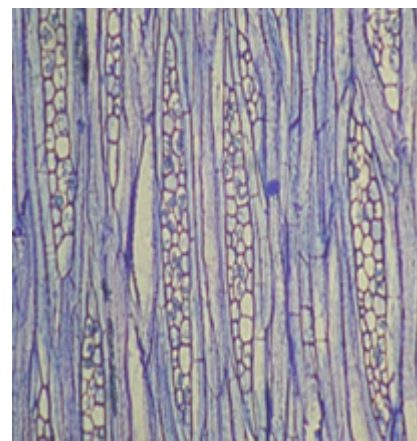

Figure 8: TLS of Phloem with Parenchyma \& Sieve Elements

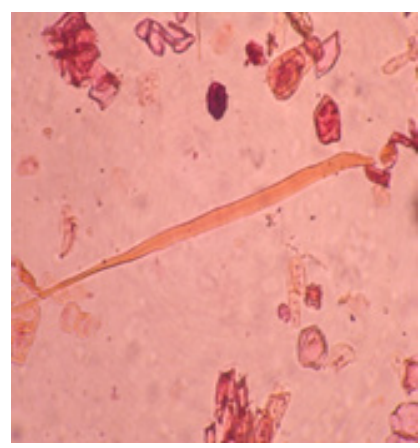

Figure 12: Bark -Fibre tracheids

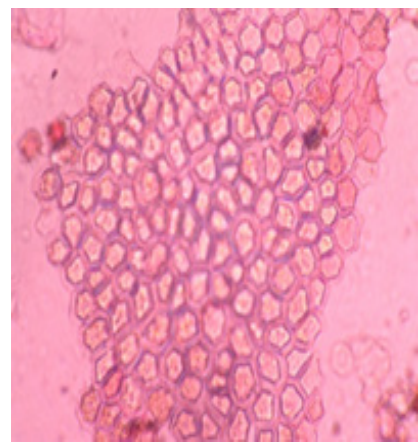

Figure 16: Periderm cells-Bark 


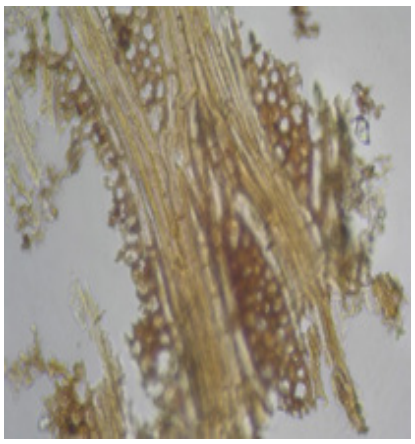

Figure 17: Phloem rays-Bark

\section{Table 1: Physico-chemical Analysis}

$\begin{array}{ccc}\text { Standardized Parameter } & \text { Leaf }(\% \mathrm{w} / \mathrm{w}) & \text { Bark }(\% \mathrm{w} / \mathrm{w}) \\ \text { Moisture Content } & 7.0 & 8.5 \\ \text { Total Ash } & 7.0 & 8.75 \\ \text { Acid Insoluble ash } & 1.0 & 0.5 \\ \text { Water soluble extractive } & 20.5 & 26.5 \\ \text { Alcohol soluble extractive } & 7.0 & 12.5 \\ \text { Chloroform soluble extractive } & 22.5 & 27.5 \\ \text { Total alkaloid content } & 4.4 & 11.06\end{array}$

Table 2: Phytochemical Analysis

\begin{tabular}{cccccccc} 
Phytoconstituent & \multicolumn{2}{c}{$\begin{array}{c}\text { Petroleum } \\
\text { ether }\end{array}$} & \multicolumn{2}{c}{ Chloroform } & \multicolumn{2}{c}{ Methanol } \\
& Bark & Leaf & Bark & Leaf & Bark & Leaf \\
Carbohydrates & - & + & - & + & + & + \\
Proteins \& Amino acids & + & + & + & + & + & + \\
$\begin{array}{c}\text { Phenolic compounds \& } \\
\text { Tannins }\end{array}$ & - & + & - & + & + & + \\
Alkaloids & + & + & + & + & + & + \\
Saponins & - & - & - & - & - & - \\
Flavonoids & - & - & + & + & + & + \\
Fixed oils \& Fats & + & + & + & + & - & - \\
Acids & - & - & - & - & - & + \\
Starch & - & - & - & - & - & - \\
Emodols & - & - & - & - & - & - \\
Quinones & - & + & - & + & - & - \\
Phytosterols & + & + & + & + & - & -
\end{tabular}

*(+): Present; (-) : Absent

Table 3: Fluorescence Analysis

\begin{tabular}{|c|c|c|c|c|c|c|}
\hline \multirow[t]{2}{*}{ Reagent } & \multicolumn{2}{|c|}{ Visible/Day Light } & \multicolumn{2}{|c|}{ UV $254 \mathrm{~nm}$} & \multicolumn{2}{|c|}{ UV $366 \mathrm{~nm}$} \\
\hline & Bark & Leaf & Bark & Leaf & Bark & Leaf \\
\hline Powder & Light Brown & Light Green & Light greenish brown & Light green & Greenish brown & Light green \\
\hline Aqueous Sodium hydroxide1M & Light Brown & Greenish red & Light green & Light green & Dark Green & Greenish black \\
\hline Alcoholic Sodium hydroxide 1M & Light Brown & Greenish Orange & Light greenish brown & Light Green & $\begin{array}{l}\text { Dark greenish } \\
\text { brown }\end{array}$ & Dark Green \\
\hline Hydrochloric acid $1 \mathrm{M}$ & Brownish green & Green & Green & Light green & Dark green & Dark green \\
\hline Nitric acid $50 \%$ & Yellowish green & Greenish yellow & Green & Light green & Dark green & Greenish black \\
\hline Sulphuric acid $1 \mathrm{M}$ & $\begin{array}{l}\text { Light brownish } \\
\text { green }\end{array}$ & $\begin{array}{l}\text { Dark brownish } \\
\text { green }\end{array}$ & Light green & $\begin{array}{l}\text { Dark brownish } \\
\text { green }\end{array}$ & None & Dark green \\
\hline Picric acid $1 \%$ & Yellowish green & Yellowish green & Green & Green & Greenish blue & Greenish black \\
\hline
\end{tabular}

matter associated with the plant. Moisture content of bark and leaf were found to be $8.5 \& 7 \%$ respectively which are low enough to discourage the growth of Micro-organisms.

\section{CONCLUSION}

The present research area helps in setting the standards for proper identification, authentication and also for the standardization of crude herbal drugs. Alphonsea sclerocarpa despite of its huge therapeutic potential is least explored due to the lack of sufficient standardization parameters and hence this research helps in validating this raw material for use in herbal formulations in the upcoming era.

\section{ACKNOWLEDGEMENT}

The authors are grateful to JNTU anantapur, Ananthapuramu and Plant Anatomy research Centre for providing all the necessary facilities to carryout the work.

\section{CONFLICT OF INTEREST}

No conflict of interest are declared.

\section{REFERENCES}

1. Ram HR, Prasad S, Dixit PK. Studies on Morphological Features and Biological Activities of the Genus Annona of Ethiopia, N. E. Africa with a Special Emphasis on Graviola: A Review, Int Journal of Science and Research. 2016;2(2):821-7.

2. Biba VS, Amily A, Sangeetha S, Remani P. Anti-cancer, Anti-oxidant and Antimicrobial activity of Annonaceae family. World Journal of Pharmacy \& Pharma- 
ceutical Sciences. 2014;3(3):1595-604.

3. Mabberley, DJ, Plant Book. $3^{\text {rd }}$ ed. Cambridge: Cambridge University Press. 2008;1021.

4. Nair NC, Henry AN. Flora of Tamilnadu, India. 1983, pp.03.

5. Chetty M, Sivaji K, Rao TK. Flowering plants of Chittoor District, Andhra Pradesh, India. 4. 2013;15.

6. Kumar DC, Pharmacognosy can help minimise accidental misuse of herbal medicine Curr Sci. 2007;93(10):1356-8

7. Fransworth NR; Biological and Phytochemical screening of plants. J Pharm Sci. 1996;55(3):25-269

8. O'Brien TP, Feder N, Mc Cull, M.E. Polychromatic Staining of Plant Cell walls by toluidine blue-O. Protoplasma. 1964;59(2):364-73. http://dx.doi.org/10.1007/ BF01248568.

9. Sass JE. Elements of Botanical Microtechnique. McGraw Hill Book Co; New York. 1940;222.
10. WHO. Quality Control Methods for Medicinal Plant Materials. (An authorized publication of World Health Organisation, Geneva). A.I.T.B.S. Publishers \& Distributors, New Delhi. 2002.

11. Chase CR, Pratt R. Fluorescence of powdered vegetable drug with particular reference to development of a system of identification. J Am Pharm Assoc. 1948;38(6):324-31. http://dx.doi.org/10.1002/jps.3030380612.

12. Kokate C, Purohit A, Gokhale S. Practical Pharmacognosy. Vallabh Prakashan, Delhi. 1999;10:107-11.

13. Wagner $\mathrm{H}$, Bladt S. Plant drug analysis: A Thin Layer Chromatography Atlas. New York: Springer-Verlag Berlin Heidelberg, $2^{\text {nd }}$ ed.; 1984. http://dx.doi. org/10.1007/978-3-662-02398-3.

14. Peach K, Tracy MV. Modern Methods of Plant Analysis, Springer-Verlag, Heidelberg. 1955;3-4.

15. Bhattacharya S, Zaman MK. Pharmacognostical evaluation of Zanthoxylum nitidum Root. Phcog J. 2009;1(1):15-21.

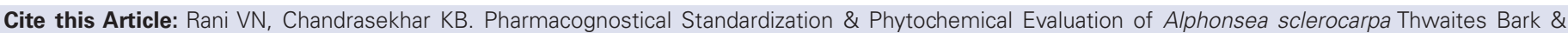
Leaves. Pharmacogn J. 2017;9(2):196-200. 